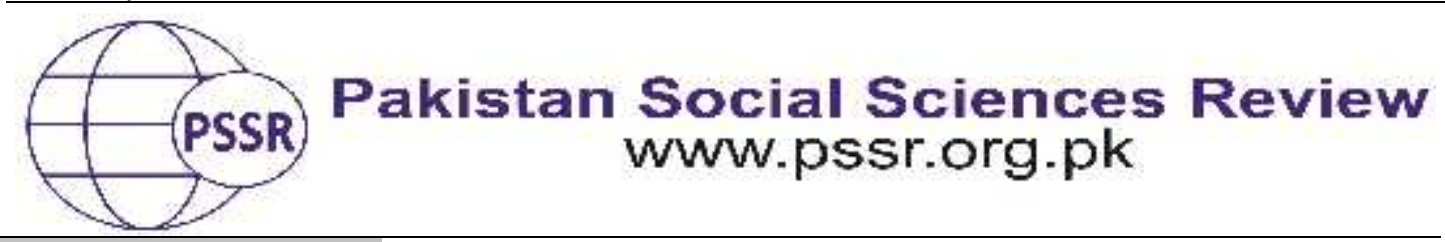

RESEARCH PAPER

\title{
Total Quality Management Implementation and Performance of Public Sector Universities in Pakistan
}

\author{
Hajra Bibi ${ }^{1}$ Abdul Waheed ${ }^{2}$ Kiran Shehzadi ${ }^{3}$
}

1. Lecturer, Department of Education, Fatima Jinnah Women University, Rawalpindi, Punjab, Pakistan

2. Assistant Professor, Faculty of Management Sciences, Foundation University Islamabad, Pakistan

3. Lecturer, Department of Education, University of Education Lahore, Punjab, Pakistan

\begin{tabular}{|c|c|}
\hline PAPER INFO & ABSTRACT \\
\hline $\begin{array}{l}\text { Received: } \\
\text { March 28, } 2021 \\
\text { Accepted: } \\
\text { May 01, } 2021 \\
\text { Online: } \\
\text { May 15, } 2021\end{array}$ & $\begin{array}{l}\text { This article discusses the relationship between implementation } \\
\text { of total quality management practices and performance of the } \\
\text { public sector universities of the Punjab. Study was quantitative } \\
\text { in nature and survey method was used for data collection. } \\
\text { Sample included department heads, faculty members and }\end{array}$ \\
\hline $\begin{array}{l}\text { Keywords: } \\
\text { Pakistan, } \\
\text { Performance, } \\
\text { Public Sector } \\
\text { Universities, } \\
\text { Total Quality } \\
\text { Management }\end{array}$ & $\begin{array}{l}\text { students of faculty of social sciences. Major findings of the study } \\
\text { indicated that there is strong positive relation between } \\
\text { implementation of TQM practices and performance of public } \\
\text { sector universities of Punjab. Further, study explored that many } \\
\text { TQM practices are implemented in public sector universities of } \\
\text { Punjab, Pakistan except involvement of stakeholders and }\end{array}$ \\
\hline $\begin{array}{l}\text { *Corresponding } \\
\text { Author } \\
\text { kiran.shahzadi@ } \\
\text { ue.edu.pk }\end{array}$ & $\begin{array}{l}\text { students in quality improvement process. On the basis of } \\
\text { findings it is recommended that public sector universities may } \\
\text { adopt TQM practices including involvement of stakeholders and } \\
\text { students in quality improvement process. Leadership plays } \\
\text { prime role in the successful implementation of TQM practices. }\end{array}$ \\
\hline
\end{tabular}

\section{Introduction}

Concept of quality has gained popularity in every sector, particularly in the last few decades. Total Quality Management (TQM) is an obvious and proved approach for the achievement of desired results. It has been proved as change management since 1980s as McAdam, Leonard, Henderson and Hazlett (2008) stated that history of TQM traced back to 1920s originated by Shewhart a statistician. Mostly concept of TQM is associated with manufacturing industry but it is also grasping attention in service sector. Related literature indicates that outcomes of TQM are equally productive in service sector as in manufacturing and industrial sector (Mustafa \& Bon, 2012).

Like other sectors, education sector is also paying attention towards the quality oriented practices. Higher education institutions are striving to meet the 
expectations of its stakeholders in order to sustain their credibility in the market place. Education is a broad field, it is performing multiple tasks such as; provision of civilized, skillful, and well equipped and train individuals to the various sectors of society (Altahayneh, 2014). Therefore, quality of other sectors mainly relies on the quality of education. TQM is a holistic approach which includes all aspects of an organization for betterment and improvement. Researchers developed different frameworks of TQM implementation and every sector adopted most appropriate framework according to their own needs and requirements. Research studies reveal that TQM practices are frequently using by industrial and corporate sector and achieving their desired outcomes. Mustafa and Bon (2012) stated that successful implementation of TQM practices bring positive results and assist in enhancing organizational performance. Organizational improvement and achieving desired outcomes require continuous efforts and it also needs to focus on the holistic development rather than improvement of one aspect. TQM focuses on organization wide improvement and educational institutions are now implementing various practices of TQM which they are considered most compatible. Some practices of TQM are common which have gained popularity in service sector too and TQM experts admitted vital contribution of TQM practices in uplifting quality of service sector's organizations. Researchers conducted their research in higher education institutions and they shared suitability and compatibility of TQM practices with education sector (Rosa \&Amaral, 2007; Jusoh, Yusoff \& Mohtar, 2008; Bayraktar, Tatoglu\&Zaim, 2008; Pandi, Rao \& Jeyathilagar, 2009).

Advance countries took initiative for adopting TQM practices in education sector and revealed positive outcomes and this initiative encouraged other countries too for the adoption of TQM. In developing countries it is still at evolving stage this is why TQM implementation process is facing different challenges such as lack of understanding of TQM practices in education, resistance from team members and lack of leadership commitment are widely explored factors which create hindrance in successful implementation of TQM in education sector (Vlasic, Vale \&Puhar, 2009). Keeping in view importance of TQM, researchers in academia sector, are trying to pay their attention towards the practices which are related to the successful implementation of TQM (Faisel, 2010; Zwain, Lim\& Othman, 2014). After conducting various studies researchers find out some practices which are equally useful and beneficial for industrial and education sector.

This study also included those TQM practices which are validated by literature as useful and appropriate practices for education such as: leadership involvement, dissemination of vision, continual improvement, employee involvement, reorganization and reward, education and training, students' involvement and involvement of other stakeholders. All these practices of TQM are highly recommended by experts for implementation of successful quality program (Crosby, 1980; Deming, 1986; Feigenbaum, 1986;Kanji\& Baker, 1990). These practices are important in enhancement of organizational image one cannot undermine the significance of any one of these practices. Performance of organization mainly relies on these aspects (Zwain, Lim\& Othman, 2014). Quality education is a major 
challenge for today's education system in Pakistan. Increasing popularity of TQM provoked education sector to rethink about their quality program and work according to those frameworks which meaningfully contribute to overall institutional performance. A lot of strategies and plans have been devised and implemented in order to achieve quality education but it is still an unachieved goal. As TQM is a novice approach to education sector and different researchers are trying to uncover the aspects which are related to implementation of total quality management in education and they came out with various results. Current study was also designed in the fulfillment of the need to find out the influence ofTQM practices on organizational performance in education sector.

Various studies have been carried out in industrial and manufacturing sector to explore the concept of TQM from different angle (Eriksson \& Hansson, 2003; Venkatraman, 2007). Therefore, many authors gave concept of TQM from their own point of views which expanded the literature and significantly contributed in the existing body of knowledge. In the education context, Sallis (2005) defined TQM as a philosophy behind continuous improvement, which is capable of providing any educational institution with a set of essential practices for meeting and exceeding present and future customers' needs, wants, and expectations. Various studies have been carried out to identify those practices that can be used in constituting the TQM paradigm (Montes, Jover, \& Fernandez, 2003; Vouzas \& Psychogios, 2007). Generally, however, the literature does not identify a single, meaningful definition for the practices of TQM, but rather presents a set of practices, which are considered essential for the establishment of TQM (Karia \&Asaari, 2006).

Literature exposes that there are some practices of TQM which are commonly used by both industrial and service sector (Vouzas \& Psychogios, 2007). According to Tari, (2005) practices of TQM can be viewed from three different perspectives: contributions from quality gurus, empirical studies, and quality standard models. On the basis of a thorough review and synthesis of TQM literature, researchers have identified nine key practices of TQM in the education context. These practices of TQM are namely: (1) leadership commitment, (2) strategic planning, (3) continuous improvement, (4) student focus, (5) process focus, (6) academic staff involvement, (7) training and learning, (8) rewards and recognition, and (9) management by fact. Previous studies indicated that TQM practices are significantly playing their role in organizational performance. These practices included all the crucial aspects of TQM and these aspects are strongly related with quality improvement (Kanji \&Baker, 1990; Evans \& Dean, 2003; Taylor \& Wright, 2003; Bayraktar, Tatoglu\& Zaim,2008).This study included the practices which widely used in education sector such as; leadership involvement, quality vision, continual improvement, employees' involvement, training and education, recognition and reward and stakeholders' involvement. Leadership involvement is core element for successful implementation of quality program. Literature supports the necessity of leadership involvement in implementation of TQM practices widely (Perles, 2002).Vision provides direction to organization and motivates employees towards its attainment. It gives the 
organization a purpose of existence and directions to efforts. Involvement and training of employees is an integral part of TQM which leads towards betterment and innovation. Employees' involvement enhances outcomes of organization and they also attain the ownership of employees. Students' and other stakeholders' involvementin quality improvement process are one of the important practices which influence the quality improvement process positively. TQM eradicates status quo and promote change with continuous efforts. All these practices are crucial for success because they enhance the performance of organization (Karia\&Asaari, 2006).

\section{Organizational Performance}

Performance is not a general term rather it is context specific term which is associated with phenomena being studied. In the context of TQM performance measurement is an integral part of this approach. Performance measurement provides picture regarding achievement, current situation and also set future direction. The basic idea behind performance measurement is improvement and betterment in existing system and optimization of performance. There are various methods for performance measurement but two ways, objective and subjective performance measurement, are widely being used for evaluation. Objective performance includes more quantitative measurement of performance and provides information about product, quantity, profit and budget. While subjective performance is based on personal judgment and satisfaction of respondents or evaluators about the services of their organizations (Gibbs, Merchant, Stede \&Vargus, 2005). In this study, performance evaluation is based on subjective aspect of performance in which students (as customers) and teaching faculty (as employees) gave their feedback regarding the services of their universities. Feedback covered the aspects; fulfillment of students' expectations, students' satisfaction, service quality, retention with institution, overall institutional performance. Study found the relationship between implementation of TQM practices and performance of public sector universities of Punjab.

\section{Relationship between TQM Practices and Organization Performance}

Many researchers studied the impact of TQM on the performance of organization. Study conducted by Karia and Asaari(2006) showed that TQM practices like leadership, process management, information and analysis and customer focus is positively related to the quality performance. Montes, Jover and Fernandez (2003) explored that transactional leadership which includes the exchange process relates positively to the organizational performance. Furthermore, with the help of visionary leadership, subordinates apply their hidden potential more positively towards the organization and hence performance will be improved. Moreover, the results of Venkatraman (2007) study showed that there is a positive and significant effect of leadership on the organization performance. Similarly, study conducted by Mustafa and Bon(2012) revealed that leadership and the humanresource management both have a significant positive effect on the performance of the organization. 
Mostly previous studies, particularly in education sector focused on leadership in order to measure the organizational performance. While there are other core practices which need to be studied in relation with organizational performance. As Sandbakken (2006) stated that besides leadership, developing sound vision, continuous improvement, employee empowerment and stake holders' involvement are also most important to the organizational performance. Therefore, it is important to shift the focus of attention from solo aspect that is leadership and turn it towards the inclusion of other important TQM practices with organizational performance.

Joiner (2007) concluded that degree of TQM implementation is positively related to organization performance. His findings show that enhancement of implementation of TQM, the greater would be the performance. Further, the greater the firm satisfies the customer needs, motivates its employees and makes continuous improvement; the higher would be the performance. More the organization implements TQM, greater would be the performance.

Haider (2008) made a conclusion that the extent of implementation of TQM factors including leadership, quality of information, implementation of the strategies, human resource management and meeting expectation of the customers has a significant effect on the performance. Valmohammadi (2011) conducted study in the manufacturing sector concluded that the TQM factors such as leadership, process management and customer focus affect the organizational performance. Related studies showed that there is a positive impact of afore said variables on the performance but mostly these studies were carried out in the industrial and corporate sector very few in education field particularly in the context of Pakistan. This study was an attempt to bridge the gap by conducting study in education sector in order to explore the relationship between TQM practices and performance of public sector universities of Punjab.

\section{Material and Methods}

This study was conducted to explore the relationship between implementation total quality management practices and performance of public sector universities of Punjab, Pakistan.

\section{Design of the Study}

Study was quantitative in nature and a survey was conducted to collect the data. It was aimed to explore relationship between TQM practices and performance of public sector universities. Both descriptive (Mean Score) and inferential statistics (Correlational and Regression Analysis) were applied to analyze the data.

\section{Population of the Study}


Heads of the departments, faculty members and students of faculty of social sciences from the public sector universities of Punjab was the population of the study.

\section{Sample of the Study}

Sample of the study comprises of Heads of the departments'47and 475 faculty members of faculty from social sciences were selected by census. Census is a method which enables every member of the population to be included in the sample. Students, 1458, from faculty of social sciences were also included in the study and they were $30 \%$ of the population. Students from each university were selected by using proportionate sampling technique.

\section{Instrumentation of the Study}

Standardized instruments were used in the study after taking permission from the authors Jose, Juan and Jose (2003); Kanning and Hill (2013). Validity and reliability of the questionnaires were calculated in order to ensure the usability of questionnaires in local context. Instrument of TQM practices obtained 0.880 reliably that is a good score. Reliability of performance measurement tool is 0.915 which is a high computed reliability. As the alpha coefficients were all greater than 0.7, a conclusion was drawn that the instruments had an acceptable reliability coefficient and were appropriated for the study.

\section{Data Collection}

Survey method was used for data collection and after screening of the data complete filled questionnaires were included for data analysis. Data were analysis by using SPSS, following is detail of analysis.

\section{Results and Discussion}

Findings of the study showed that there is strong positive relationship between implementation of TQM practices and performance of public sector universities. Following figure shows correlation between TQM practices and performance of public sector universities. 


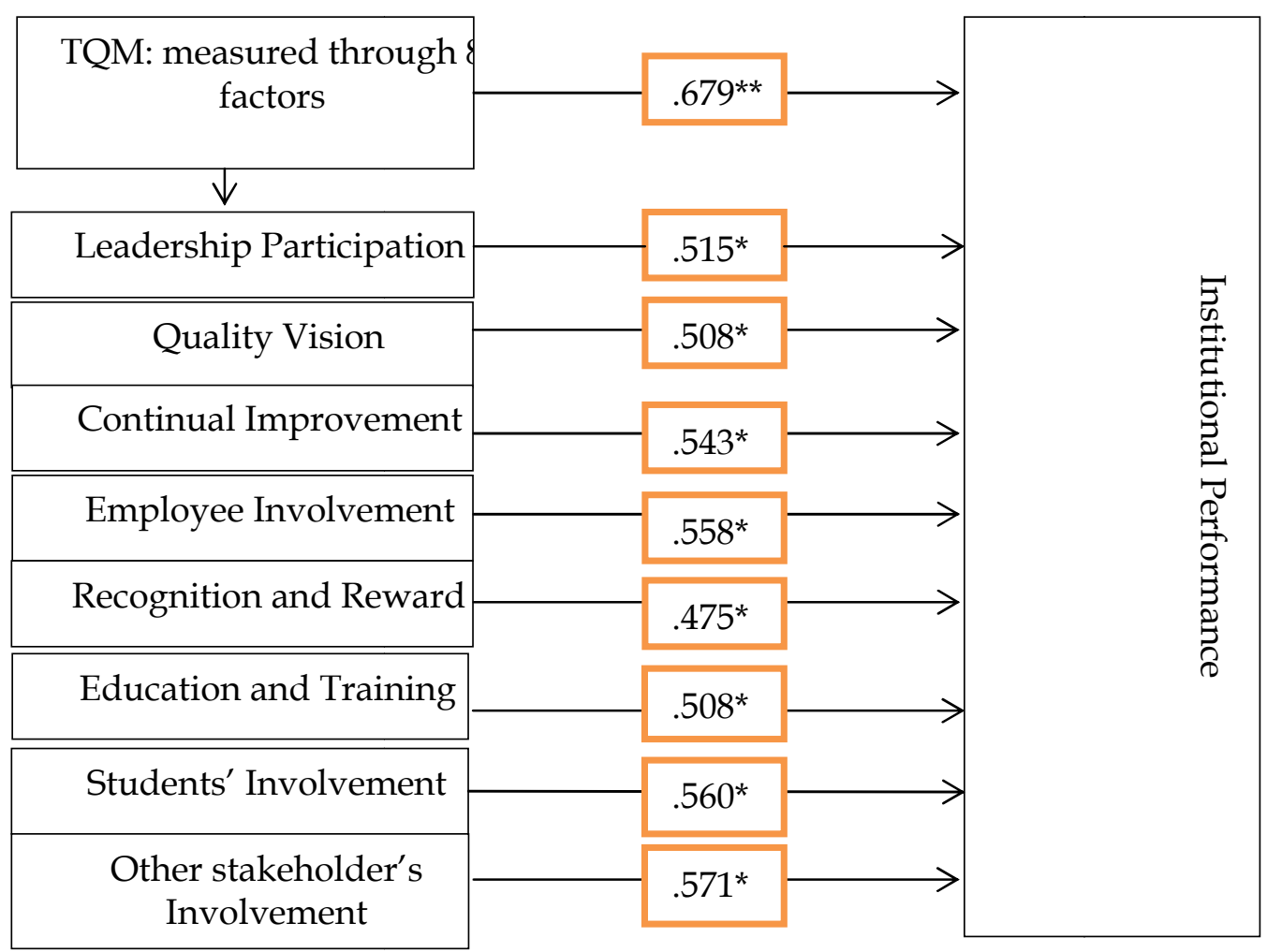

Figure 1: TQM Critical Success Factors Based on the Study Relationship Matrix

* indicates the correlations value is significant even at .01 confidence level.

Figure 1indicates that overall Total Quality Management (TQM) has quite high positive correlation with performance of public sector universities. Enhancing TQM practices would lead to enhancement of institutional performance and decrease in the implementation of TQM principals would mean decrease in institutional performance. Relationship between TQM practices and performance of institutions can be seen in figure 2 sector plot which clearly indicates the tendency of relationship between two variables.

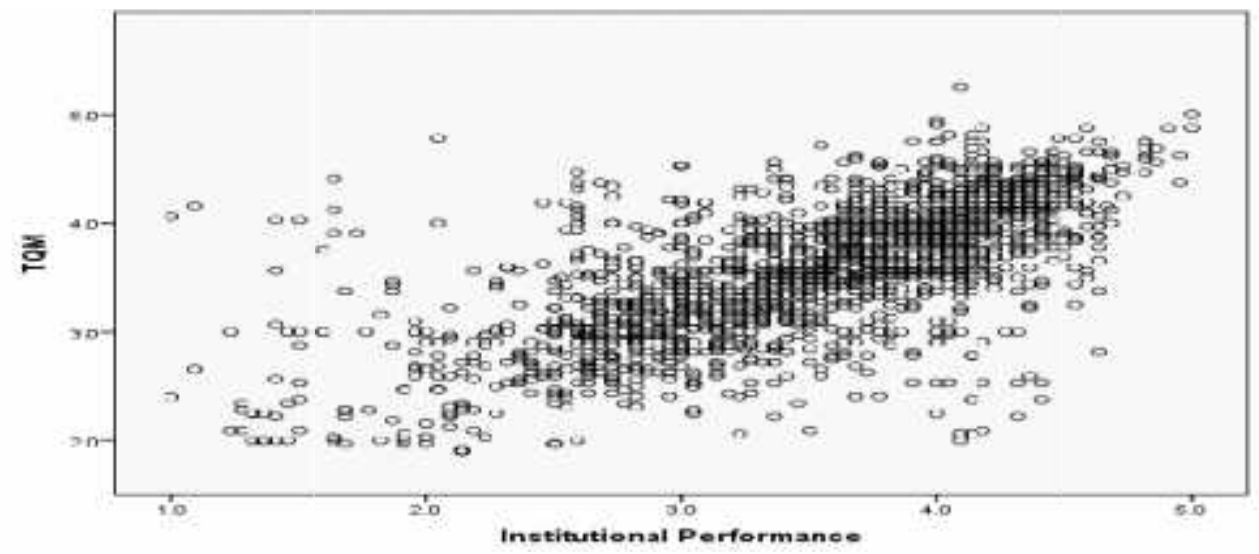

Figure 2: Relationship between TQM and Institutional Performance 
Figure 2 shows strong positive relationships between TQM and institutional performance. Nature of relationship between TQM practices and institutional performance indicates a positive relationship between the two variables.

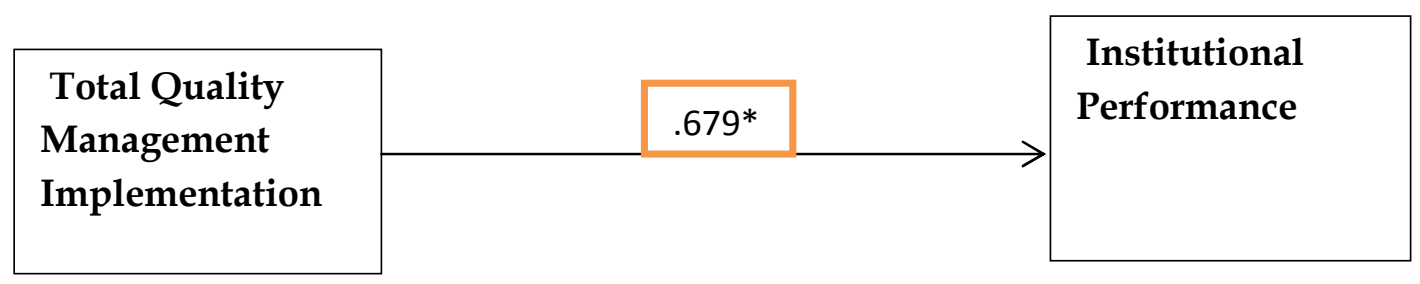

Figure 3: TQM Implementation and Institutional Performance

Figure 3shows that TQM has strong correlation with performance. Implementation of TQM practices can bring visible improvement in institutional performance.

Table 1

Regression Analysis of TQM And Intuitional Performance

\begin{tabular}{ccccccc}
\hline Variables & Mean & SD & R-square & $\boldsymbol{F}$ & $\boldsymbol{d f}$ & $\boldsymbol{P}$ \\
\hline Constant (HEOs) & 3.502 & .717 & .461 & 1662.199 & 1 & .000 \\
\hline $\begin{array}{c}\text { TQM (Predicting } \\
\text { variable)Variables }\end{array}$ & 3.573 & .604 & & & & \\
\hline
\end{tabular}

Table 1 shows simple linear regression was applied in order to obtain the predictability of performance by implementation of TQM practices. The R-square value in Table 2 indicates that $46 \%$ of variability in performance score can be predicted by the implementation of TQM practices. Regression analysis shows that implementation of TQM practices can enhance the performance of institution up to the value of $46 \%$.

\section{Conclusion}

On the basis of findings of the study it is concluded that TQM practices have strong positive relationship with institutional performance. All practices of total quality management contribute significantly to uplift the standard of education particularly at higher education level where students are mature enough to take part as internal stakeholders in improving quality of education. To conclude it can be said that the higher ratio of implementation of TQM practices leads towards the higher performance of the institution. In future a comparative study can be conducted in public and private universities which may be beneficial for both sectors to take lessons from each other and also helpful in identification of areas of improvement. 


\section{References}

Altahayneh, Z. L. (2014). Implementation of total quality management in colleges of physical education in Jordan. International Journal of Business and Social Science, 5(3), 156-168.

Bayraktar, E., Tatoglu, E., \&Zaim, S. (2008). An instrument for measuring the critical factors of TQM in Turkish higher education. Total Quality Management, 19(6), 551 -574 .

Crosby, P. B. (1980). Quality is free. New York: McGraw-Hill. https://books.google.com.pk/books/about/Quality_is_Free.html?id=n4IubCcp $\underline{\mathrm{m} 0 \mathrm{EC} \& \mathrm{rediresc}=\mathrm{y}}$.

Deming, W. E. (1986). Out of the crisis. Cambridge: MIT Center for Advanced Engineering Study.

Eriksson, H., \& Hansson, J. (2003). The impact of TQM on financial performance. Measuring Business Excellence, 7(1), 36-50.

Evans, J. R., \& Dean, J. W. (2003). Total Quality: Management, Organization, and Strategy. Mason, OH: Thomson South-Western.

Faisel, Y. (2010). Statistics Using SPSS: An integrative approach, second edition. Journal of Applied Statistics, 37(2), 2119-2120.

Feigenbaum, A.V. (1986). Total quality control. Singapore: McGraw-Hill.

Gibbs, J. M., Merchant, A. K., Stede, V. A.W., \&Vargus, E. M. (2005). The benefits of evaluating performance subjectively. Performance Improvement, 44(5), 26-32.

Kanji, G. K., \& Baker, R. L. (1990). Implementation of total quality management. Total Quality Management, 1(3), 375-389.

Karia, N., \&Asaari, M. H. (2006). The effects of total quality management practices on employees' work-related attitudes. The TQM Magazine, 18(1), 30-43.

Haider, S. Z. (2008). Challenges in higher education: Special reference to Pakistan and South Asian developing countries. Nonpartisan Education Review, 4(2), 1-12.

Joiner, T. A. (2007). Total quality management and performance: The role of organization support and co-worker support. International Journal of Quality $\mathcal{E}$ Reliability Management, 24(6), 617-627.

Jose, F. C., Juan, L., \& Jose, J. T. (2004). Development of a measure to assess quality management in certified firms. European Journal of Operational Research, 156(3), 683-697. 
Jusoh, A., Yusoff, R. Z., Mohtar, S. (2008). Determining TQM practices in university $\mathrm{R} \& \mathrm{D}$ activities using factor analysis: Research experience of Malaysian universities. Journal Kemanusiaan Bill, 11(2), 133-142.

McAdam, R., Leonard, D., Henderson, J., \&Hazlett, S. A. (2008). A grounded theory research approach to building and testing TQM theory in operations management. Omega, 36(5), 825-837.

Montes, F. J., Jover, A.V., \& Fernandez, L.M.M. (2003). Factors affecting the relationship between total quality management and performance. International Journal of Quality E Reliability Management, 20(2), 189-209.

Mustafa, E., \& Bon, A. T. (2012). Role of top management leadership and commitment in total quality management in service organization in Malaysia: a review and conceptual framework. https:/ / papers.ssrn.com/sol3/papers.cfm?abstract_id=2200013

Pandi, A. P., Rao, U. S., Jeyathilagar, D. (2009). A study on Integrated Total Quality Management Practices in Technical Institutions-Students' Perspective. International Journal of Educational Administration, 1(1), 355-364.

Perles, G. S. M. (2002). The ethical dimension of leadership in the programs of total quality management. Journal of Business Ethics, 39(2), 59-66.

Rosa, M. J. \&Amaral, A. (2007). A Self-Assessment of Higher Education Institutions from the Perspective of the EFQM Excellence Model. Quality Assurance in Higher Education, 20 (3), 181-207.

Sandbakken, D. A. (2006). Leadership Practices and Organizational Performance. EDAMBA Journal, 7(2), 215-223.

Sallis, E. (2005). Total Quality Management in Education. London: Kogan Page.

Tari, J. J. (2005). Components of successful total quality management. The TQM Magazine, 17(2), 182-194.

Taylor, W. A., \& Wright, G. H. (2003). A longitudinal study of TQM implementation: Factors influencing success and failure. Omega, 31(3), 97-111.

Valmohammadi, C. (2011). The impact of TQM implementation on the organizational performance of Iranian manufacturing SMEs. The TQM Journal, 23(5), 496-509.

Venkatraman, S. (2007). A framework for implementing TQM in higher education programs. Quality Assurance in Education, 15(1), 92-112.

Vlasic, S., Vale, S., \&Puhar, D. K. (2009). Quality management in education. Interdisciplinary Management Research, 5(1), 565-573. 
Vouzas, F., \&Psychogios, A. G. (2007). Assessing managers' awareness of TQM. The TQM Magazine, 19(1), 62-75.

Zwain, A. A. A., Lim, K. T., \& Othman, S. N. (2014). TQM practices and organizational knowledge creation: An empirical study of Iraqi higher education institutions. Asian Journal of Business and Accounting, 7(1), 232-244. 